\title{
PENENTUAN MODEL PREMI TIDAK KONSTAN PADA ASURANSI DANA PENSIUN
}

\author{
Lia Jenita $^{\S 1}$, I Nyoman Widana ${ }^{2}$, Desak Putu Eka Nilakusmawati ${ }^{3}$ \\ ${ }^{1}$ Jurusan Matematika Fakultas MIPA - Universitas Udayana [Email:liajenitat@ gmail.com] \\ ${ }^{2}$ Jurusan Matematika Fakultas MIPA - Universitas Udayana [Email:nwidana@yahoo.com] \\ ${ }^{3}$ Jurusan Matematika Fakultas MIPA - Universitas Udayana [Email:nilakusmawati@unud.ac.id] \\ ${ }^{\S}$ Corresponding Author
}

\begin{abstract}
Pension plan is an effort to anticipate the life of old on the day. In the pension program, there are two methods of normal due's calculation to be paid by the insured each year, the Entry Age Normal method, namely calculation of normal dues with constant premiums and projected unit credit method, namely calculation of normal dues with Premium Increases Each year or is not constant. This paper wants to develop an inconstant premium calculation method with constant premium increase annually. Where the pension plan participants' age when he joined the pension plan is 19 years and the retirement age on this contract is 55 years, with premium increases of $5 \%$ of the normal dues early. The large ratio of premiums is, $P_{E A N}>P_{\text {Konstan baru }}>P_{P U C}$ for dues normal at the age of 19 years until the age of 28 years, but $P_{\text {Konstan baru }}>P_{E A N}>P_{P U C}$ for dues normal at the age of 29 years to the age of 33 years and $P_{P U C}>P_{\text {Konstan baru }}>P_{E A N}$ to normal dues at the age of 34 years old until the age of one year before retirement.
\end{abstract}

Keyword: Entry Age Normal, futures contract, Premium Increases Each, constant premium increase annually

\section{PENDAHULUAN}

Asuransi dana pensiun merupakan salah satu bentuk upaya perencanaan masa tua dengan tujuan menjamin kesejahteraan hidup pada saat memasuki usia pensiun. Program Asuransi adalah suatu program yang mengupayakan sejumlah pertanggungan dengan pihak-pihak yang terlibat, yaitu pihak penanggung (perusahaan asuransi) dan pihak tertanggung (individual atau kelompok sebagai pemegang polis). Pihak penanggung memberikan jaminan suatu pengganti kerugian yang dialami atau diderita tertanggung sesuai perjanjian dan kesepakatan kedua belah pihak. Pihak tertanggung memiliki kewajiban untuk membayarkan sejumlah uang yang disebut dengan premi sesuai polis yang disepakati kedua belah pihak pada awal perjanjian asuransi.

Oleh karena itu, Dana pensiun atau sering disebut asuransi hari tua adalah asuransi yang mengupayakan sejumlah nilai manfaat (benefit) pensiun bagi pesertanya yang bertujuan membentuk sejumlah dana untuk dapat dipergunakan nantinya di hari tua setelah mereka tidak bekerja lagi.

Menurut UU No.11 Tahun 1992 yang berisikan tentang hal-hal yang menyangkut tentang dana pensiun. Selain sebagai bentuk jaminan masa tua para pegawai yang bekerja di perusahaannya, dana pensiun juga merupakan salah satu tanggung jawab perusahaan terhadap semua pegawai yang telah bekerja keras selama masa kerjanya di perusahaan itu.

Pada asuransi dana pensiun, ada beberapa kesepakatan yang harus disetujui oleh pihak tertanggung dan pihak penanggung. Kesepakatan itu adalah premi dan aktuaria, dimana besar premi yang akan dibayarkan oleh pihak tertanggung (pegawai) asuransi dana pensiun harus disesuaikan dengan penghasilan yang didapatkan, sehingga besar iuran premi yang akan dibayarkan tidak membebani tertanggung. Pembayaran premi akan dilakukan 
dalam bentuk pembayaran iuran normal dilakukan dalam bentuk pemotongan gaji pegawai. Gaji yang dipotong menjadi investasi selama masa kerja dan akumulasi dana untuk pembayaran manfaat pensiun dalam memelihara kesinambungan penghasilan peserta pada hari tua (Futami [2]).

Dalam melakukan perhitungan premi, penulis menggunakan formula baru yaitu perhitungan premi tidak konstan dengan kenaikan premi tiap tahunnya konstan. Metode ini adalah metode perhitungan normal cost dengan mengalokasikan total manfaat pensiun secara merata sejak tanggal perhitungan aktuaria. Metode tersebut menggunakan asumsi skala gaji yang akan diestimasi pada masa depan (future value) dan diasumsikan bahwa gaji mengalami peningkatan.

Menurut Futami [3], jika seseorang berinvestasi sebesar Rp.1,- pada saat sekarang dan tingkat bunga yang berlaku sebesar $i$, maka total pokok besar bunga sebesar bunga setelah $i$ tahun adalah:

$$
v^{t}=\frac{1}{(1+i)^{t}} \text {. }
$$

Besar total manfaat yang didapatkan selama tertanggung aktif bekerja dari umur $e$ tahun sampai dengan $r$ tahun, dinotasikan $b_{r}$ sehingga besar manfaat yang akan diterima oleh tertanggung pada tahun $x$ dinotasikan $b_{x}$ (Sembiring [5]).

$$
b_{x}=\frac{b_{r}}{r-e}
$$

Manfaat yang didapatkan oleh peserta pensiun merupakan proporsi gaji sebesar $k$ persen yang kemudian diakumulasikan sesuai waktu yang telah ditentukan selama $(x-e)$ dan berdasarkan skala gaji berikut:

\section{a. Asumsi Gaji Terakhir}

Gaji terakhir pada usia $r-1$ tahun yang diharapkan dinotasikan dengan

$$
s_{r-1}=(1+s)^{r-1-x} s_{x} .
$$

b. Asumsi Rata-Rata Gaji Selama Bekerja

Rata-rata gaji yang diharapkan selama bekerja adalah

$$
\begin{aligned}
& \frac{1}{r-e}\left[s_{e}+\cdots+s_{x}+s_{x+1}+\cdots+s_{r-1}\right] \\
= & \frac{1}{r-e}\left[\frac{s_{x}}{(1+s)^{x-e}}+\cdots+s_{x}+(1+s) s_{x}+\cdots+\right. \\
& \left.(1+s)^{x-e+1} s_{x}\right] \\
= & \frac{1}{r-e} s_{x}(1+s)^{e-x}\left[1+\cdots+(1+s)^{x-e}+\right. \\
& \left.\quad(1+s)^{x-e+1}+\cdots+(1+s)^{r-e-1}\right]
\end{aligned}
$$

Nilai akhir anuitas yang dilakukan selama $r-e$ tahun dengan peningkatan sebesar $s$ dinotasikan dengan $s_{r-e} \mid s$, sehingga persamaan di atas dapat ditulis menjadi:

$$
\frac{1}{r-e} s_{x}(1+s)^{e-x} s_{r-e} \mid s .
$$

Sehingga diperoleh manfaat pensiun tertanggung sampai berusia $x$ tahun adalah

$B_{x}=\frac{k}{r-e}\left[s_{x}(1+s)^{e-x} s_{r-e} \mid s\right](x-e)$

Present Value of Future Benefit (PVFB) adalah nilai sekarang dari manfaat pensiun yang akan diterima oleh tertanggung saat memasuki usia pensiunnya atau $r$ tahun. Sistem pembayaran manfaat pensiun yang dilakukan tiap tahun sampai tertanggung meninggal.

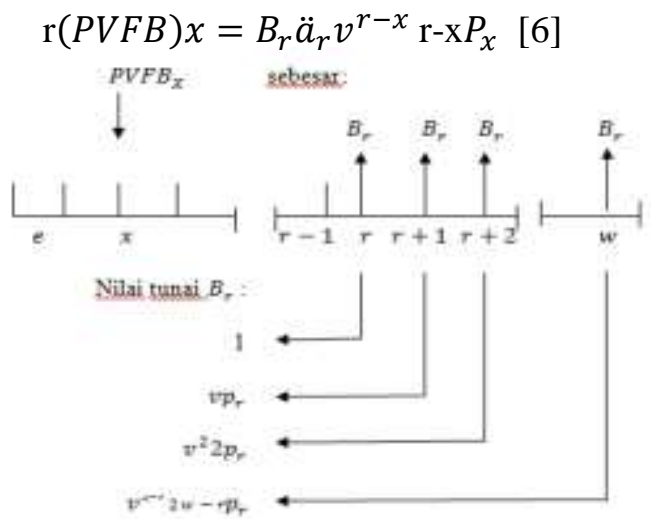

Gambar 1. Skema Pembayaran

Keterangan:

$$
\begin{aligned}
{ }^{\mathrm{r}}(P V F B) x= & \text { nilai sekarang dari manfaat } \\
& \text { pensiun normal di usia } \mathrm{x} \text { tahun; } \\
B_{r} & \text { besar manfaat pensiun normal; } \\
\ddot{a}_{r} & \text { nilai sekarang dari anuitas } \\
& \text { seumur hidup di usia pensiun } r \\
& \text { tahun; } \\
= & \text { faktor diskonto selama }(r-x) \\
& \text { tahun; dan } \\
v^{r-x} & \text { tingkat penyusutan aktuaria total } \\
& \\
& \text { di usia } \mathrm{x} \text { tahun hingga usia } r \\
& \text { tahun }
\end{aligned}
$$


Present value of future normal cost (PVFNC) adalah nilai sekarang dari iuran normal yang dibayarkan secara berkala oleh peserta dimulai dari peserta berusia $x$ tahun sampai memasuki usia pensiun berusia $r-1$ tahun, yang dinotasikan dengan $\operatorname{r}(P V F N C) x$. Besar pembayaran berkala iuran normal yang dilakukan setiap awal tahun sebesar $N C$ dimulai dari peserta masuk program pensiun (usia $a$ tahun) sampai memasuki usia pensiun selang waktu usia $r-1$ tahun dapat dijelaskan dengan skema pembayaran tampak pada Gambar 2 .

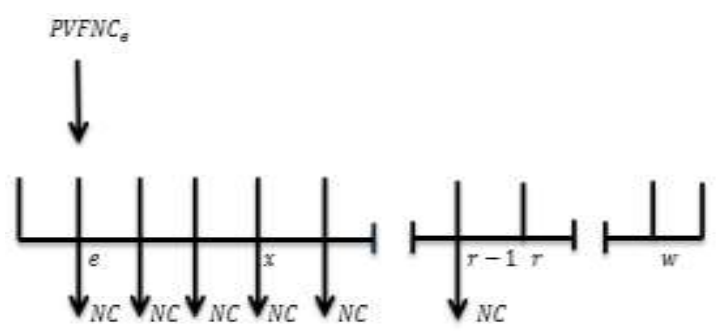

Gambar 2. Skema Pembayaran Iuran Normal Selama Masa Kerja

Berdasarkan skema pada Gambar 2 pembayaran iuran normal selama masa kerja tertanggung selang waktu usia a tahun sampai dengan berusia $r-1$ tahun adalah

$$
\begin{aligned}
& 1+\mathrm{vp}_{\mathrm{a}}+\mathrm{v}^{2} 2 \mathrm{p}_{\mathrm{a}}+\cdots+\mathrm{v}^{\mathrm{r}-1-\mathrm{a}} \mathrm{r}-1-\mathrm{ap} \mathrm{p}_{\mathrm{a}} \\
& =\mathrm{v}_{\mathrm{L}}^{\mathrm{t}-\mathrm{x}} \quad \mathrm{t}-\mathrm{x}_{\mathrm{x}} .
\end{aligned}
$$

Sehingga nilai sekarang iuran normal pada saat tertanggung berusia $\mathrm{x}$ tahun yang dinotasikan dengan $r(\text { PVFNC })_{\mathrm{X}}$ dan dirumuskan sebagai berikut

$$
\mathrm{r}(\text { PVFNC })_{\mathrm{x}}=\sum_{\mathrm{t}=\mathrm{x}}^{\mathrm{r}-1}(\mathrm{NC})_{\mathrm{t}} \mathrm{v}_{\mathrm{L}}^{\mathrm{t}-\mathrm{x}}{ }_{\mathrm{t}-\mathrm{x}} \mathrm{p}_{\mathrm{x}}
$$

\section{Metode Perhitungan Premi}

Metode Entry Age Normal adalah nilai sekarang dari manfaat pensiun yang akan datang akan sama dengan nilai sekarang iuran normal (premi) yang akan datang pada saat berusia pensiun $\mathrm{y}$.

Pada dasarnya, iuran normal yang akan dibayarkan oleh tertanggung secara berkala (PVFNC) pada selang usia $\mathrm{x}$ tahun sampai $\mathrm{r}$ tahun, dipergunakan untuk melakukan pembayaran manfaat (PVFB) yang nantinya akan diberikan kepada tertanggung pada saat pensiun. Nilai sekarang dari iuran normal saat peserta berusia $x$ tahun adalah $r(\text { PVFNC })_{x}$ sedangkan nilainya akan sama dengan nilai sekarang manfaat pensiun saat tertanggung berusia $x$ tahun yaitu $\mathrm{r}(\mathrm{PVFB})_{\mathrm{x}}$ (Nurcahyani \& Endang [4]), sehingga diperoleh persamaan:

$$
\mathrm{r}(\mathrm{PVFB})_{\mathrm{x}}=\mathrm{r}(\mathrm{PVFNC})_{\mathrm{x}}
$$

Sehingga berdasarkan persamaan (7) dan (8), maka nilai NC dapat dirumuskan sebagai berikut:

$$
\begin{aligned}
& (\mathrm{PVFB})_{\mathrm{X}}=(\mathrm{PVFNC})_{\mathrm{X}} \\
& \mathrm{B}_{\mathrm{r}} \ddot{\mathrm{a}}_{\mathrm{r}} \mathrm{v}^{\mathrm{r}-\mathrm{x}} \mathrm{r}-\mathrm{x} \mathrm{P}_{\mathrm{x}}=\sum_{\mathrm{t}=\mathrm{x}}^{\mathrm{r}-1}(\mathrm{NC})_{\mathrm{t}} \mathrm{v}_{\mathrm{L}}^{\mathrm{t}-\mathrm{x}}{ }_{\mathrm{t}-\mathrm{x}} \mathrm{p}_{\mathrm{x}} \\
& \sum_{\mathrm{t}=\mathrm{x}}^{\mathrm{r}-1}(\mathrm{NC})_{\mathrm{t}} \mathrm{v}_{\mathrm{L}}^{\mathrm{t}-\mathrm{x}} \quad{ }_{\mathrm{t}-\mathrm{x}} \mathrm{p}_{\mathrm{x}}=\mathrm{B}_{\mathrm{r}} \ddot{\mathrm{a}}_{\mathrm{r}} \mathrm{v}^{\mathrm{r}-\mathrm{x}} \mathrm{r}-\mathrm{xP}_{\mathrm{x}} \\
& \mathrm{NC} \sum_{\mathrm{t}=\mathrm{x}}^{\mathrm{r}-1} \mathrm{v}_{\mathrm{L}}^{\mathrm{t}-\mathrm{x}} \quad{ }_{\mathrm{t}-\mathrm{x}} \mathrm{p}_{\mathrm{x}}=\mathrm{B}_{\mathrm{r}} \ddot{\mathrm{a}}_{\mathrm{r}} \mathrm{v}^{\mathrm{r}-\mathrm{x}} \mathrm{r}-\mathrm{x} \mathrm{P}_{\mathrm{x}} \\
& \operatorname{EAN}(N C)=\frac{B_{r} \ddot{a}_{r} v^{r-x} r-x P_{x}}{\sum_{t=x}^{r-1} v_{L}^{t-x}{ }_{t-x} p_{x}} \\
& \operatorname{EAN}(N C)=\frac{B_{r} \ddot{a}_{r} v^{r-x} r-x P_{x}}{\ddot{a}_{\bar{x}: r-x}}
\end{aligned}
$$

\section{Metode Projected Unit Credit}

Metode Projected Unit Credit (PUC) adalah merupakan metode perhitungan iuran normal yang membagi total manfaat pensiun pada saat usia pensiun. Dimana total dari masa kerja peserta pensiun menjadi suatu unit manfaat pensiun yang kemudian dialokasikan pada setiap tahun pada masa kerja (Bower,et al. [7]).

Iuran normal (NC) seorang peserta yang berusia $\mathrm{x}$ dan pensiun pada usia $r$ didefinisikan sebagai nilai sekarang dari manfaat yang akan terima peserta pensiun dimasa yang akan datang $(\mathrm{PVFB})_{\mathrm{x}}$ dan akan menyebar secara merata setiap tahunnya selama masa kerja $(\mathrm{r}-\mathrm{x})$ (Futami [3]). Sehingga iuran normal untuk metode ini dapat dirumuskan sebagai berikut:

$$
\begin{aligned}
\text { PUC(NC) } & =\frac{1}{(r-e)} B_{r} \ddot{a}_{r} v^{r-x} r-x P_{x} \\
& =\frac{1}{(r-e)}(P V F B)_{x}
\end{aligned}
$$

\section{HASIL DAN PEMBAHASAN}

\section{Model (formula) Premi Tidak Konstan}

Pada tahapan ini akan dicari formula premi tidak konstan dengan kenaikan yang konstan setiap tahunnya sebesar $\alpha$. Adapun rincian kontrak dalam program asuransi adalah sebagai berikut, mulai menjadi peserta program pensiun 
saat berusia e tahun dan akan terhitung pensiun pada usia $r$ tahun.

Misalkan $\mathrm{P}$ adalah nilai tunai yang harus di bayarkan tertanggung setiap tahunnya. Pada tahun pertama tertanggung membayarkan iuran sebasar $\mathrm{P}$ dan tahun kedua sebesar $\alpha+\mathrm{P}$ dan seterusnya mengalami peningkatan sebesar $\alpha$ setiap tahunnya sampai mencapai usia pensiun satu tahun sebelum. Sehingga besar iuran terakhir yang akan dibayarkan tertangngung adalah $(r-1)+P$. Sebaliknya sebagai hak yang akan didapatkan peserta pensiun bila hidup sampai usia $\mathrm{r}-1$, akan mendapatkan tanggungan (uang pensiun) mulai usia $r$ tahun sebesar $B_{r}$ seumur hidup. Apabila peserta pensiun meninggal sebelum mencapai usia $r-$ 1, maka peserta pensiun tidak mendapatkan uang tanggungan apapun. Dari kontrak ini maka nilai tunai dari premi yang akan dibayarkan peserta pensiun adalah:

$$
\begin{aligned}
& (P V F N C)_{e}=\frac{\left[\begin{array}{c}
\mathrm{P} \mathrm{l}_{\mathrm{e}}+\mathrm{v}(\mathrm{P}+\alpha) \mathrm{l}_{\mathrm{e}+1}+\mathrm{v}^{2}(\mathrm{P}+\alpha) \mathrm{l}_{\mathrm{e}+2}+\cdots \\
+\mathrm{v}^{\mathrm{r}-\mathrm{e}-1}\{\mathrm{P}+\alpha(\mathrm{r}-1-\mathrm{e})\} \mathrm{I}_{\mathrm{r}-1}
\end{array}\right]}{\mathrm{l}_{\mathrm{e}}} \\
& =\frac{\left[\begin{array}{c}
\mathrm{P} \mathrm{l}_{\mathrm{e}}+\mathrm{v}(\mathrm{P}+\alpha) \mathrm{l}_{\mathrm{e}+1}+\mathrm{v}^{2}(\mathrm{P}+\alpha) \mathrm{l}_{\mathrm{e}+2} \\
+\cdots+\mathrm{v}^{\mathrm{r}-\mathrm{e}-1}\{\mathrm{P}+\mathrm{a}(\mathrm{r}-1-\mathrm{e})\} \mathrm{l}_{\mathrm{r}-1}
\end{array}\right]}{\mathrm{l}_{\mathrm{x}}} \cdot \frac{\mathrm{v}^{\mathrm{e}}}{\mathrm{v}^{\mathrm{e}}} \\
& =\frac{\left[\begin{array}{c}
\mathrm{Pl}_{\mathrm{e}} \mathrm{v}^{\mathrm{e}}+\left\{\mathrm{v}(\mathrm{P}+\alpha) \mathrm{l}_{\mathrm{e}+1}\right\} \mathrm{v}^{\mathrm{e}}+\left\{\begin{array}{c}
\mathrm{v}^{2}(\mathrm{P}+\alpha) \\
\mathrm{l}_{\mathrm{e}+2}
\end{array}\right\} \\
\mathrm{v}^{\mathrm{e}}+\cdots+\left\{\mathrm{v}^{\mathrm{r}-\mathrm{e}-1}\{(\mathrm{P}+\alpha)\} \mathrm{l}_{\mathrm{r}-1\} \mathrm{v}^{\mathrm{e}}}\right.
\end{array}\right]}{\mathrm{l}_{\mathrm{e}} \mathrm{v}^{\mathrm{e}}} \\
& =\frac{1}{\mathrm{D}_{\mathrm{e}}}\left[\mathrm { P } \left(\mathrm{D}_{\mathrm{e}}+(\mathrm{P}+\alpha) \mathrm{D}_{\mathrm{e}+1}+(\mathrm{P}+\alpha+\right.\right. \\
& \left.\left.\alpha) D_{\mathrm{e}+2}+\cdots+\{\mathrm{P}+(\mathrm{r}-1-\mathrm{e}) \alpha\} \mathrm{D}_{\mathrm{r}-1}\right)\right] \\
& =\frac{1}{\mathrm{D}_{\mathrm{e}}}\left[\mathrm{P}\left(\mathrm{D}_{\mathrm{e}}+\mathrm{D}_{\mathrm{e}+1}+\mathrm{D}_{\mathrm{e}+2}+\cdots+\mathrm{D}_{\mathrm{r}-1}\right)+\right. \\
& \alpha\left(D_{\mathrm{e}+1}+\mathrm{D}_{\mathrm{e}+2}+\cdots+\mathrm{D}_{\mathrm{r}-1}\right)+ \\
& \left.\alpha\left(\mathrm{D}_{\mathrm{e}+2}+\cdots+\mathrm{D}_{\mathrm{r}-1}\right)+\alpha\left(\mathrm{D}_{\mathrm{r}-1}\right)\right] \\
& =\frac{1}{D_{\mathrm{e}}}\left[\mathrm{P}\left(\mathrm{N}_{\mathrm{e}}-\mathrm{N}_{\mathrm{r}}\right)+\alpha\left(\mathrm{N}_{\mathrm{e}+1}-\mathrm{N}_{\mathrm{r}}\right)+\right. \\
& \left.\alpha\left(\mathrm{N}_{\mathrm{e}+2}-\mathrm{N}_{\mathrm{r}}\right)+\alpha\left(\mathrm{N}_{\mathrm{r}-1}-\mathrm{N}_{\mathrm{r}}\right)\right] \\
& =\frac{1}{\mathrm{D}_{\mathrm{e}}}\left[\mathrm{P}\left(\mathrm{N}_{\mathrm{e}}-\mathrm{N}_{\mathrm{r}}\right)+\alpha\left(\mathrm{S}_{\mathrm{e}+1}-\mathrm{S}_{\mathrm{r}}\right)-\right. \\
& \alpha(\mathrm{r}-1-\mathrm{e}) \mathrm{N}_{\mathrm{r}} \text { ] }
\end{aligned}
$$

Sehingga diperoleh nilai sekarang dari iuran normal (premi) yang dibayarkan peserta pensiun adalah :

$$
\begin{gathered}
(\mathrm{PVFNC})_{\mathrm{e}}=\frac{1}{\mathrm{D}_{\mathrm{e}}}\left[\mathrm{P}\left(\mathrm{N}_{\mathrm{e}}-\mathrm{N}_{\mathrm{r}}\right)+\alpha\left(\mathrm{S}_{\mathrm{e}+1}-\mathrm{S}_{\mathrm{r}}\right)-\right. \\
\left.\alpha(\mathrm{r}-1-\mathrm{e}) \mathrm{N}_{\mathrm{r}}\right]
\end{gathered}
$$

Sedangkan untuk nilai tunai dari manfaat pensiun yang akan dibayarkan oleh perusahaan asuransi pensiun bagi peserta pensiun adalah:

$$
\begin{aligned}
(P V F B)_{e} & =\frac{B_{r}\left(l_{r} v^{r-e}+l_{r+1} v^{r-e}+\cdots\right)}{l_{e}} \\
& =\frac{B_{r}\left(l_{r} v^{r-e}+l_{r+1} v^{r-e}+\cdots\right)}{l_{e}} \cdot \frac{v^{e}}{v^{e}} \\
& =B_{r} \ddot{a}_{r} v^{r-e}{ }_{r-e} P_{e}
\end{aligned}
$$

Berdasarkan prinsip ekuivalensi yang telah dijelaskan terlebih dahulu pada persamaan (9) dimana nilai uang yang masuk kedalam perusahaan harus sama dengan nilai uang yang dikeluarkan perusahaan. Sehingga dengan mengunakan persamaan ekuivalensi dari persamaan (11) dan (12) maka akan diperoleh persamaan:

$$
\begin{aligned}
& \frac{1}{D_{\mathrm{e}}}\left[\mathrm{P}\left(\mathrm{N}_{\mathrm{e}}-\mathrm{N}_{\mathrm{r}}\right)+\alpha\left(\mathrm{S}_{\mathrm{e}+1}-\mathrm{S}_{\mathrm{r}}\right)-\alpha(\mathrm{r}-1-\mathrm{e}) \mathrm{N}_{\mathrm{r}}\right]= \\
& B_{r} \ddot{a}_{r} v^{r-e}{ }_{r-e} p_{x} \\
& {\left[\mathrm{P}\left(\mathrm{N}_{\mathrm{e}}-\mathrm{N}_{\mathrm{r}}\right)+\alpha\left(\mathrm{S}_{\mathrm{e}+1}-\mathrm{S}_{\mathrm{r}}\right)-\alpha(\mathrm{r}-1-\mathrm{e}) \mathrm{N}_{\mathrm{r}}\right]=} \\
& \mathrm{B}_{\mathrm{r}} \ddot{a}_{\mathrm{r}} \mathrm{v}^{\mathrm{r}-\mathrm{e}} \mathrm{r}-\mathrm{e} \mathrm{p}_{\mathrm{x}} \mathrm{D}_{\mathrm{e}} \\
& {\left[P\left(N_{e}-N_{r}\right)\right]=B_{r} \ddot{a}_{r} v^{r-e}{ }_{r-e} p_{x} D_{e}-\alpha\left(S_{e+1}-S_{r}\right)+} \\
& \alpha(\mathrm{r}-1-\mathrm{e}) \mathrm{N}_{\mathrm{r}} \\
& {[\mathrm{P}]=\frac{\left(\mathrm{B}_{\mathrm{r}} \ddot{a}_{\mathrm{r}} \mathrm{v}^{\mathrm{r}-\mathrm{e}}{ }_{\mathrm{r}-\mathrm{e}} \mathrm{p}_{\mathrm{x}} \mathrm{D}_{\mathrm{e}}\right)-\alpha\left(\mathrm{S}_{\mathrm{e}+1}-\mathrm{S}_{\mathrm{r}}\right)+\alpha(\mathrm{r}-1-\mathrm{e}) \mathrm{N}_{\mathrm{r}}}{\left(\mathrm{N}_{\mathrm{e}}-\mathrm{N}_{\mathrm{r}}\right)}}
\end{aligned}
$$

Dimana [P] menyatakan besar iuran normal pada tahun pertama, sehingga besar premi pada tahun ke_t adalah:

$[\mathrm{P}]_{\mathrm{t}}=\mathrm{P}+\alpha(\mathrm{t}-1), \quad \mathrm{t}=1,2,3, \ldots,(\mathrm{r}-\mathrm{e})$

\section{Contoh Kasus Penerapan}

Berdasarkan rumusan masalah yang telah dijelaskan pada bab sebelumnya, maka akan diberikan contoh kasus yang berkaitan dengan permasalahan pada penelitian ini (Nurcahyani \& Endang [4]). Dalam hal ini, bila seorang karyawan mulai menjadi peserta pensiun semenjak berusia 19 tahun $(\mathrm{e}=19)$ dan akan terhitung pensiun pada usia 56 tahun $(r=56)$, dengan gaji pokok terakhir yang diterima karyawan yang diakumulasikan dalam satu tahun adalah sebesar Rp.13.848.000,-. Perhitungan (valuasi) dilakukan pada saat peserta berusia 24 tahun. Kemudian untuk tahun berikutnya iuran normal yang akan dibayar ditambahkan dengan $\alpha$ sebesar 5\% dari besar manfaat pensiun dengan tingkat suku bunga sebesar $11 \%$ dan $\mathrm{k}$ sebesar 2,5\% adalah:

\section{a. Perhitungan Manfaat Pensiun}

Seperti yang telah dijelaskan pada bagian sebelumnya, pada penelitian ini perhitungan 
manfaat pensiun untuk premi tindak konstan dengan peningkatan secara konstan, digunakan asumsi rata-rata gaji yang diperoleh karyawan selama masih aktif bekerja sebagai berikut:

Pada contoh kasus yang disajikan telah di ketahui gaji pokok terakhir yang diterima karyawan yaitu sebesar Rp. 13.848.000,- maka selanjutnya untuk menentukan besar manfaat pensiun berdasarkan besar gaji terakhir dapat menggunakan persamaan(2) sehingga diperoleh:

$$
\begin{aligned}
\mathrm{b}_{\mathrm{r}} & =\mathrm{ks}_{\mathrm{r}-1}(\mathrm{r}-\mathrm{e}) \\
& =2,5 \%(13.848 .000)(56-19) \\
& =\text { Rp. } 12.809 .400,-
\end{aligned}
$$

\section{b. Perhitungan Nilai Sekarang Manfaat Pensiun (Present Value of Future Benefit)}

Pada kasus perhitungan nilai iuran premi tidak konstan dengan kenaikan konstan, pada penelitian ini menggunakan asumsi skala rata rata gaji selama pegawai (peserta pensiun) selama masih aktif bekerja sebagai berikut:

$$
\begin{aligned}
56(\mathrm{PVFB})_{24}= & \mathrm{B}_{56} \frac{\mathrm{N}_{56}}{\mathrm{D}_{56}} \mathrm{v}^{56-23} 56-23 \mathrm{p}_{23}^{(\mathrm{T})} \\
= & \mathrm{B}_{56} \ddot{\mathrm{a}}_{56} \mathrm{~V}^{56-23} 56-23 \mathrm{p}_{23}^{(\mathrm{T})} \\
= & 12.809 .400 \frac{903,0301628}{997,5984618} \\
& (0,047362441)\left(\frac{26,52721817}{26,52721817}\right) \\
= & 12.809 .400(0,904201637) \\
& (0,047362441)(1) \\
= & \text { Rp. } 3.050 .779,355
\end{aligned}
$$

Jadi, diperoleh nilai sekarang total manfaat pensiun yang akan di peroleh peserta program pensiun saat mencapai usia 23 tahun sebesar Rp.59.225.742,-.

Sehingga diperoleh nilai $\alpha$ adalah:

$$
\begin{aligned}
& \alpha=\left(\operatorname{EAN}_{(\mathrm{NC})^{\mathrm{x}}}\right) * 5 \% \\
& =(184 \cdot 263,35) 5 \% \\
& =\text { Rp. } 9.213,167447
\end{aligned}
$$

\section{c. Perhitungan Iuran Normal (Premi)}

\section{Perhitunan Iuran Normal Metode Entry Age Normal}

Berdasarkan persamaan (9) diperoleh iuran normal yang akan dibayarkan peserta program dana pensiun adalah:

$$
\operatorname{EAN}(N C)=\frac{B_{r} \ddot{a}_{r} v^{r-x} r-x P_{x}}{\ddot{a}_{\bar{x}: r-x}}
$$

$$
\begin{aligned}
& =\frac{(\text { PVFB })_{\mathrm{e}}}{\ddot{a}_{\mathrm{e}: \mathrm{r}-\mathrm{e}}} \\
& =\frac{1790716,26}{9,7182} \\
& =\operatorname{Rp} \cdot 184263,35
\end{aligned}
$$

\section{Perhitunan Iuran Normal Metode Projected Unit Credit}

Berdasarkan persamaan (10) diperoleh iuran normal yang akan dibayarkan peserta program dana pensiun adalah:

$$
\begin{aligned}
\text { PUC(NC) } & =\frac{1}{(\mathrm{r}-\mathrm{e})}(\text { PVFB })_{\mathrm{x}} \\
& =\frac{1}{(56-19)} 3050779,35 \\
& =\text { Rp. 82453,50 }
\end{aligned}
$$

\section{Perhitungan Nilai Iuran Normal dengan Formula Baru}

Perhitungan iuran yang harus dibayarkan oleh peserta pensiun pada penelitian ini, dimana pada setiap tahunnya premi yang wajib dibayarkan peserta pensiun bertambah sebesar $\alpha$. Seperti yang telah dijelaskan pada persamaan (12), perhitungan nilai premi yang harus dibayarkan adalah:

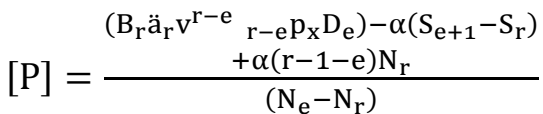

$$
\begin{aligned}
& (3.050 .779,355) * 129,4930- \\
& =\frac{\left(\begin{array}{c}
(9213.16745)\left(\begin{array}{c}
5949,5029- \\
147,4105
\end{array}\right) \\
+(9213.16745)(147,4105)
\end{array}\right)}{(744,3545-8,9130)} \\
& =\text { Rp. 109289,41 }
\end{aligned}
$$

Sedangkan untuk perhitungan iuran normal pada usia 24 tahun menggunakan persamaan (13) sehingga diperoleh:

$$
\begin{aligned}
{[\mathrm{P}]_{\mathrm{t}}=} & \mathrm{P}+\alpha(24-1) \\
= & 109289,41+9213.16745 \\
& (24-1) \\
& =\text { Rp. } 155355,24
\end{aligned}
$$

Berdasarkan perhitungan yang dilakukan pada sub bab sebelumnya, penggunaan asumsi skala gaji terakhir yang diperoleh oleh peserta pensiun digunakan untuk melakukan perhitungan nilai sekarang manfaat pensiun tiap tahun dan disajikan dalam bentuk grafik pada Gambar 3. 


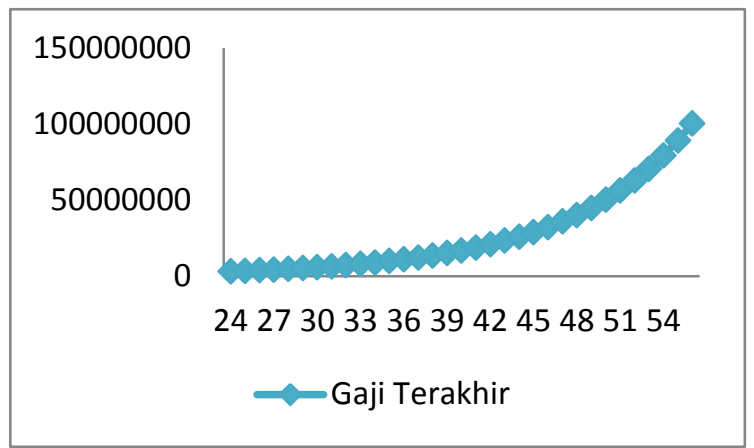

Gambar 3. Grafik Nilai Sekarang dari Manfaat Pensiun (Present Value of Future Benefit) dengan Asumsi Skala Gaji Terakhir.

Gambar 3 menunjukkan bahwa penggunaan asumsi gaji terakhir menghasilkan manfaat pensiun yang sangat tinggi. Hal ini menyatakan bahwa penggunaan skala gaji terakhir akan menunjukkan penggunaan asumsi gaji lainnya, mengingat setiap tahun pegawai selalu mendapatkan peningkatan gaji. Tetapi kekurangan saat mengunakan asumsi gaji terakhir adalah perusahaan asuransi dapat saja mengalami kerugian dikarenakan harus melakukan pembayaran kekurangan pembiayaan yang terjadi diawal masa kepesertaan bagi peserta program pensiun yang memperoleh peningkatan penghasilan tiap tahunnya.

Sedangkan untuk perbandingan, perhitungan pembiayaan iuran normal ditunjukkan pada Gambar 4.

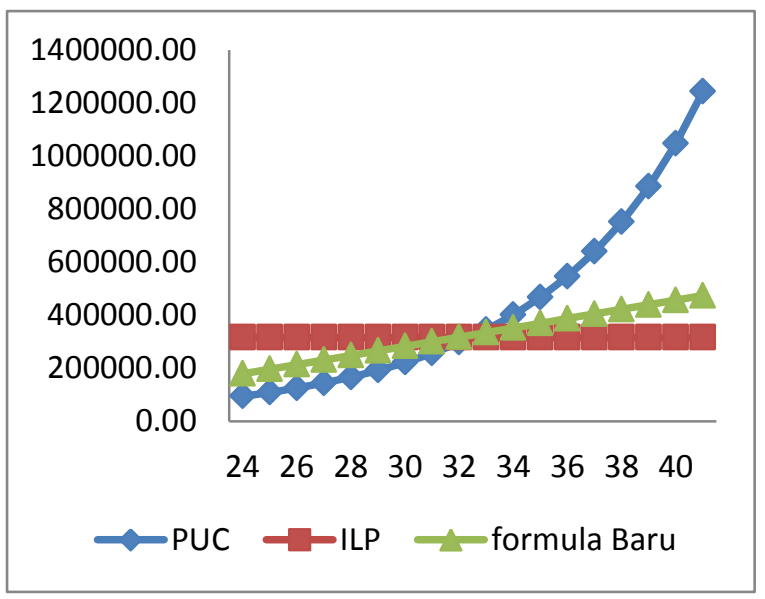

Gambar 4. Grafik Pembiayaan Iuran Normal Mengunakan Metode Projected Unit Credit (PUC), Individual Level Premium (ILP) Berdasarkan Asumsi Gaji Terakhir

Grafik garis berbentuk layang-layang yang ditunjukkan pada gambar 4 menunjukan bahwa pembiayaan iuran normal (premi) dengan mengunakan metode Projected Unit Credit akan mengalami peningkatan setiap tahunnya. Pada metode ini peningkatan iuran normal yang terjadi setiap tahunnya tidak secara konstan, sehingga pada saat peserta mencapai usia lebih tua peningkatan besar iuran normal yang harus dibayarkan peserta program dana pensiun semakin melonjak tinggi disesuaikan dengan perkiraan besar manfaat yang akan didapatkan peserta pensiun jika membayar iuran normal pada umur tersebut. Peningkatan iuran normal mengunakan metode Projected Unit Credit dapat dilihat dengan grafik garis yang berwarna biru.

Sedangkan grafik garis berbentuk pesegi yang ditunjukkan pada gambar 4 menunjukkan pembiayaan iuran normal dengan mengunakan metode Individual Level Premium. Perhitungan iuran normal (premi) dengan mengunakan metode ini cenderung tetap saat pegawai baru menjadi peserta pensiun sampai pegawai memasuki usia pensiun. Hal ini disebabkan karena perhitungan pembiayaan iuran normal dengan metode Individual Level Premium tidak dipengaruhi oleh usia peserta program dana pensiun saat tahun perhitungan aktuaria (saat peserta berusia $\mathrm{x}$ tahun), tetapi dipengaruhi oleh usia peserta program dana pensiun saat memasuki program dana pensiun (saat peserta berusia e tahun).

Sedangkan Grafik garis berbentuk persegi tiga yang ditunjukkan pada gambar 4 menunjukkan, bahwa pembiayaan iuran normal dengan menggunakan formula baru dengan kenaikan yang terjadi secara konstan. Hal ini disebabkan karena kenaikan iuran normal yang terjadi setiap tahunnya adalah sebesar $\alpha$. Dimana dengan menggunakan formula ini didapatkan iuran normal yang harus dibayarkan peserta pensiun saat baru memasuki program dana pensiun sampai akhir usia pembayaran (satu tahun sebelum usia pensiun) berada di tengah-tengah atau diantara perhitungan iuran normal dengan mengunakan perhitungan dengan metode Projected Unit Credit dan Individual Level Premium. 
Berdasarkan hasil perhitungan pembiayaan iuran normal setiap tahun, berikut ini diperoleh perbandingan hasil nilai akhir perhitungan iuran normal setiap tahunnya menggunakan tiga formula yang berbeda. Pada perhitungan ini diasumsikan bahwa setiap peserta yang memasuki program dana pensiun pada usia e tahun dan masih hidup saat memasuki usia pensiun (berusia $r$ tahun).

Berdasarkan perhitungan nilai akhir pembiayaan iuran normal, diperoleh total akhir pembiayaan iuran normal dengan Projected Unit Credit adalah sebesar Rp.12.695.636,-, sedangkan total nilai akhir pembiayaan iuran normal dengan mengunakan Entry Age Normal adalah sebesar Rp.5.896.427,-, dan total nilai akhir pembiayaan iuran normal dengan menggunakan formula kenaikan kostan adalah Rp.8.066.992,-

Penggunaan pembiayaan akhir menggunakan formula kenaikan iuran normal secara konstan, menghasilkan nilai akhir iuran yang lebih tinggi dibandingkan dengan Individual Level Premium dan lebih rendah dari nilai akhir iuran dengan menggunakan metode Projected Unit Credit. Oleh karena itu, perhitungan pembiayaan iuran normal dari sudut pandang peserta asuransi dapat memilih formula kenaikan iuran normal secara konstan. Dengan demikian, peserta pensiun tidak merasa terbebani dengan kenaikan iuran normal setiap tahunnya dikarenakan kenaikan yang terjadi setiap tahunnya selalu konstan.

\section{KESIMPULAN DAN SARAN}

Penelitian ini menunjukkan bahwa:

1. Formula model premi tidak konstan dengan kenaikan konstan pada tahun pertama adalah:

$\mathrm{P}=$

$\frac{\left(B_{r} \ddot{a}_{r} v^{r-e}{ }_{r-e} p_{x} D_{e}\right)-\alpha\left(S_{e+1}-S_{r}\right)+\alpha(r-1-e) N_{r}}{\left(N_{e}-N_{r}\right)}$

dengan $\mathrm{P}$ menyatakan besar iuran normal pada tahun pertama, sehingga besar premi pada tahun ke_t adalah:

$$
\begin{array}{r}
\mathrm{P}_{\mathrm{t}}=\mathrm{P}+\alpha(\mathrm{t}-1), \quad \mathrm{t} \\
=1,2,3, \ldots,(\mathrm{r}-\mathrm{e})
\end{array}
$$

2. Bilamana usia peserta program dana pensiun saat mengikuti program pensiun adalah 19 tahun dan usia pensiun pada kontrak ini adalah 55 tahun, dengan kenaikan premi sebesar 5\% dari iuran normal awal. Adapun besar perbandingan premi adalah sebagai berikut, $\mathrm{P}_{\mathrm{EAN}}>$ $\mathrm{P}_{\text {kenaikan konstan }}>\mathrm{P}_{\mathrm{PUC}}$ untuk iuran normal pada saat berusia 19 tahun sampai usia 28 tahun, tetapi $\mathrm{P}_{\text {kenaikan konstan }} \geq$ $\mathrm{P}_{\text {EAN }} \geq \mathrm{P}_{\mathrm{PUC}}$ untuk iuran normal pada saat berusia 29 tahun sampai usia 33 tahun dan $\mathrm{P}_{\text {PUC }}>\mathrm{P}_{\text {kenaikan konstan }}>\mathrm{P}_{\text {EAN }}$ untuk iuran normal pada saat berusia 34 tahun sampai usia satu tahun sebelum pensiun.

Adapun saran untuk pengembangan penelitian selanjutnya agar peneliti selanjutnya menggunakan asumsi tingkat suku bunga pembiayaan investasi yang berbeda. Selain itu, agar kontrak program dana pensiun yang selanjutnya dapat diperbaharui dengan kontrak program dana pensiun dimana peserta program dana pensiun tetap memperoleh pembiayaan usia tua (pensiun) pada saat peserta pensiun mengalami sesuatu kejadian dipertengahan sebelum mencapai usia pensiun.

\section{DAFTAR PUSTAKA}

[1] Aitken, W. H 1994. A Problem Solving Approach to Pensiun Funding And Valuation. 2nd edition. Winsted: Actex Publications.

[2] Futami, T. 1993a. Matematika Asuransi Jiwa Bagian I. Herliyanto, Gatot, penerjemah.Tokyo: oriental Life Insurance Cultural Development Center. Terjemahan dari: Seimei Hoken Sugaku, Jokan ("92 revision).

[3] Futami, T. 1993b. Matematika Asuransi Jiwa Bagian II. Herliyanto, Gatot, penerjemah.Tokyo: oriental Life Insurance Cultural Development Center. Terjemahan dari: Seimei Hoken Sugaku, Jokan ("92 revision).

[4] Nurcahyani, L. dan Endang W. 2014. Penentuan Model Premi dengan Metode Individual Level Premium Pada Asuransi. Jurnal. Fakultas Matematika. Universitas Brawijaya. 
[5] Sembiring, R.K. 1986. Buku Materi Pokok Asuransi I. Departemen Pendidikan dan Kebudayaan Universitas Terbuka.

[6] Winklevoss. 1993. Pengertian Dana Pensiun. http://wisuda.unud.ac.id. Diakses tangal 16 Juni 2015.

[7] Bower,et al.1997. Perhitungan Dana Pensiun dengan Metode Projected Unit Credit. http://download.portalgaruda.org. Diakses tangal 23 juli 2015. 